\title{
Lichen sclerosus mimicking mycosis fungoides preceding B-cell lymphoma - diagnostic challenges
}

\author{
Liszaj twardzinowy imitujący ziarniniaka grzybiastego poprzedzający chłoniaka \\ z komórek B - trudności diagnostyczne
}

\author{
Agnieszka Oszywa', Andrzej K. Jaworek², Grzegorz Dyduch³, Agnieszka Giza, Anna Wojas-Pelc' \\ 'Department of Dermatology, The University Hospital, Krakow, Poland \\ 2Department of Dermatology, Jagiellonian University Collegium Medicum, Krakow, Poland \\ ${ }^{3}$ Department of Pathomorphology, Jagiellonian University Collegium Medicum, Krakow, Poland \\ ${ }^{4}$ Department of Hematology, Jagiellonian University Collegium Medicum, Krakow, Poland \\ 'Oddział Kliniczny Dermatologii, Szpital Uniwersytecki w Krakowie, Polska \\ ${ }^{2}$ Katedra i Klinika Dermatologii, Uniwersytet Jagielloński Collegium Medicum w Krakowie, Polska \\ ${ }^{3}$ Katedra Patomorfologii, Uniwersytet Jagielloński Collegium Medicum w Krakowie, Polska \\ ${ }^{4}$ Katedra i Klinika Hematologii, Uniwersytet Jagielloński Collegium Medicum w Krakowie, Polska
}

\section{CORRESPONDING AUTHOR/ ADRES DO KORESPONDENCJI: dr n. med. Andrzej K. Jaworek Katedra i Klinika Dermatologii Uniwersytet Jagielloński Collegium Medicum w Krakowie tel.: +48 694486112 e-mail: andrzej.jaworek@uj.edu.pl}

\begin{abstract}
Introduction: The diagnosis of cutaneous lymphomas is extremely difficult because of their morphological diversity and clinical similarity to many dermatoses.

Objective: Presentation of the case of a 70-year-old woman diagnosed with lichen sclerosus in whom the evolution of skin lesions raised suspicions of lymphocytic hyperplasia.

Case report: The patient diagnosed with lichen sclerosus was hospitalized three times due to exacerbation of skin lesions with accompanying mycosis fungoides-mimicking infiltration. Cutaneous lymphoma was excluded in biopsy specimens collected from skin lesions. In the following months, a new nodular lesion appeared on the patient's face that turned out to be marginal zone lymphoma. After increasing the dose of methotrexate to $20 \mathrm{mg}$ / week, a rapid remission of skin lesions was achieved.

Conclusions: The presented case shows that the diagnosis of primary cutaneous lymphoma is a significant challenge in everyday dermatological practice and requires repeated biopsy.
\end{abstract}

\section{STRESZCZENIE}

Wprowadzenie: Diagnostyka chłoniaków skóry jest niezwykle trudna ze względu na ich zróżnicowanie morfologiczne i kliniczne podobieństwo do wielu dermatoz.

Cel pracy: Przedstawienie przypadku 70-letniej pacjentki z rozpoznanym liszajem twardzinowym, u której ewolucja zmian skórnych budziła podejrzenie rozrostu limfocytarnego.

Opis przypadku: Pacjentkę z rozpoznanym liszajem twardzinowym hospitalizowano trzykrotnie $\mathrm{z}$ powodu zaostrzenia zmian skórnych z towarzyszącym naciekiem imitujących ziarniniaka grzybiastego. W pobranych wycinkach ze zmian skórnych wykluczono diagnozę chłoniaka skóry. W kolejnych miesiącach doszło do pojawienia się nowej guzowatej zmiany na twarzy, która okazała się chłoniakiem strefy 
brzeżnej. Po zwiększeniu dawki metotreksatu do $20 \mathrm{mg}$ tygodniowo uzyskano szybką remisję zmian skórnych.

Wnioski: Przedstawiony przypadek wskazuje na fakt, że rozpoznanie chłoniaka pierwotnie skórnego stanowi istotne wyzwanie w codziennej praktyce dermatologicznej i wymaga ponawiania biopsji.

Key words: lichen sclerosus, mycosis fungoides, marginal zone lymphoma.

Słowa kluczowe: liszaj twardzinowy, ziarniniak grzybiasty, chłoniak strefy brzeżnej.

\section{INTRODUCTION}

Lichen sclerosus (LS) is a chronic skin disease of unknown etiology. Typically, lesions in the form of atrophic, porcelain-white plaques are located in the anogenital area, but the extragenital form of LS has been described in 15-20\% of all patients [1]. This dermatosis was included in the group of pseudolymphomas [2] - benign lymphocytic hyperplasia clinically mimicking cutaneous lymphoma. The diagnosis of cutaneous lymphomas is extremely difficult due to their large morphological diversity and clinical similarity to many dermatoses [3]. Increased oncological vigilance is always recommended in cases of atypical manifestations of skin diseases.

\section{OBJECTIVE}

Presentation of the case of a 70-year-old female patient diagnosed with LS, in whom the evolution of skin lesions raised suspicions of lymphocytic hyperplasia.

\section{CASE REPORT}

A 70-year-old woman, retired, no history of internal diseases, with disseminated skin lesions in the course of LS lasting for 2 years, was admitted to the Department of Dermatology due to the intensification of skin lesions. The first lesions appeared in the patient's vulva, followed by development of lesions on the trunk over the following year. The clinical suspicion of LS was confirmed by histopathological examination. The patient was treated with steroid ointments from groups III and IV according to the European classification. About 6 months before admission, the patient was concerned about the sudden extension of her lesions. Porcelain-white lumps with a tendency to aggregate into hardened foci (kraurosis vulvae) were observed on the labia minora (figs. 1-3).

\section{WPROWADZENIE}

Liszaj twardzinowy (lichen sclerosus - LS) jest przewlekłą chorobą skóry o nieznanej etiologii. Zwykle zmiany w postaci atroficznych, porcelanowobiałych blaszek u większości pacjentów lokalizują się w okolicy anogenitalnej, ale występowanie postaci pozagenitalnej LS opisano u 15-20\% wszystkich chorych [1]. Dermatozę tę zaliczono do grupy rzekomych chłoniaków T (pseudolymphoma) [2] - łagodnych rozrostów limfocytarnych klinicznie imitujących chłoniaka skóry. Diagnostyka chłoniaków skóry jest niezwykle trudna ze względu na duże zróżnicowanie morfologiczne i kliniczne podobieństwo do wielu dermatoz [3]. Wzmożona czujność onkologiczna jest każdorazowo wskazana w przypadkach nietypowych manifestacji chorób skóry.

\section{CEL PRACY}

Przedstawienie przypadku 70-letniej pacjentki z rozpoznanym LS, u której ewolucja zmian skórnych budziła podejrzenie rozrostu limfocytarnego.

\section{OPIS PRZYPADKU}

Kobieta 70-letnia, emerytka, nieobciążona internistycznie, z utrzymującymi się od 2 lat rozsianymi zmianami skórnymi w przebiegu LS została przyjęta do Kliniki Dermatologii z powodu nasilenia zmian skórnych. Pierwsze wykwity pojawiły się u chorej w obrębie sromu, wyprzedzając o rok wysiew zmian na tułowiu. Kliniczne podejrzenie LS potwierdzono w badaniu histopatologicznym. Pacjentka była leczona maściami glikokortykosteroidowymi z grupy III i IV wg klasyfikacji europejskiej. Około 6 miesięcy przed przyjęciem chorą zaniepokoiło nagłe poszerzenie się zmian. Na wargach sromowych mniejszych zaobserwowano porcelanowobiałe grudki $\mathrm{z}$ tendencją do skupiania w stwardniałe ogniska (kraurosis vulvae) (ryc. 1-3). 


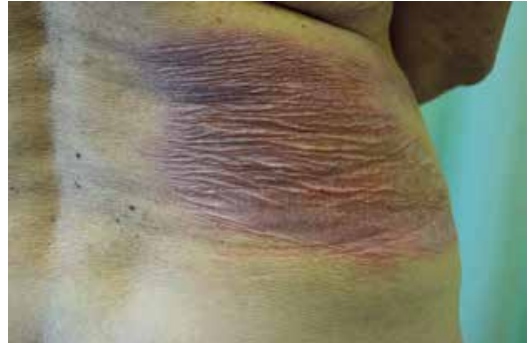

Figure I. Atrophic plague with marked, tissue paper surphace and extensive vascular component in the right lumbar region

Rycina I. Blaszka zanikowa z zaznaczonym bibułkowaniem powierzchni i nasilonym komponentem naczyniowym w prawej okolicy lędźwiowej

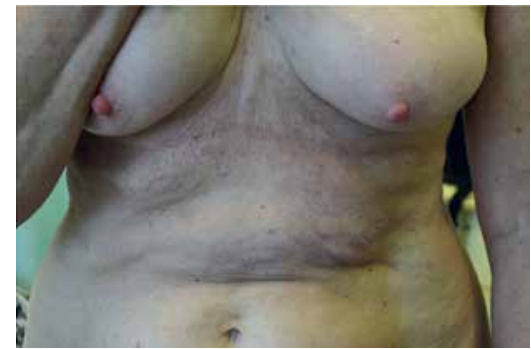

Figure 3. Atrophic lesions in the sub-breast area

Rycina 3. Zmiany zanikowe w okolicy podpiersiowej

Laboratory tests performed during hospitalization (basic tests, ANA, ANA3 antibodies, scleroderma profile) revealed the presence ANA antibodies of granular-type luminescence, with a positive division zone, at the titer 1 : 5120; DSF 70 strongly positive $(+++)$. Two deep biopsies of the skin of the buttock and the lumbosacral region were collected for histopathological examination with determination of the immunophenotype and clonality of the T-lymphocyte receptor. The examining pathomorphologist described atrophic epidermis, and swelling in the reticular layer of the dermis, without obvious thickening of collagen, and features of collagen fibers vitrification in the papillary layer. There was also a moderately profuse, perivascular and interstitial lymphocyte infiltration, partially compose of cells with hyperchromatic nuclei (fig. 4).

The expression of the CD3 marker with the CD4 : CD8 ratio of $2: 1$ dominated in the immunophenotypic study. No monoclonal proliferation of lymphocytes was detected in the PCR test. The entire tissue examination ruled out the diagnosis of lymphoma in accordance with the guidelines for the early phase diagnosis of mycosis fungoides of the Polish Dermatological Society. The treatment of LS was started with clobetasol propionate once daily topically, with improvement.

Because of emergence of subsequent foci of disease in a short time, methotrexate s.c. at the dose of $15 \mathrm{mg} /$ week was introduced. After 2 months of the therapy, enlargement of a nodular lesion with a clear

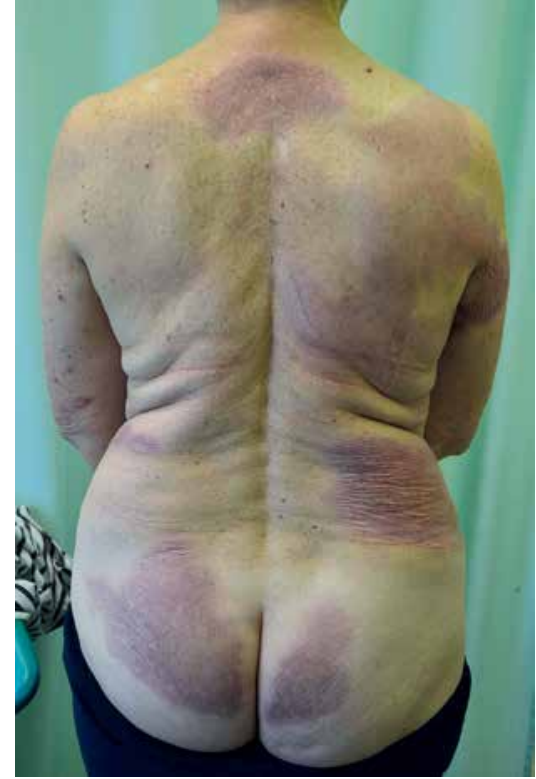

Figure 2. Diffuse, infiltrated erythematous plaques on the skin of the back and buttocks

Rycina 2. Rozsiane, nacieczone blaszki rumieniowe na skórze pleców i pośladków

W wykonanych w trakcie hospitalizacji badaniach laboratoryjnych (badania podstawowe, przeciwciała ANA, ANA3, profil twardzinowy) stwierdzono obecność przeciwciał ANA o typie świecenia ziarnistym $\mathrm{z}$ dodatnią strefą podziałów w mianie 1 : 5120; DSF 70 silnie dodatnie (+++). Pobrano dwa głębokie wycinki skóry pośladka i okolicy lędźwiowo-krzyżowej do badania histologicznego z oznaczeniem immunofenotypu i klonalności receptora limfocytów T. Patomorfolog opisał atroficzny naskórek, a w skórze właściwej obrzęk w warstwie siatkowatej bez ewidentnego pogrubienia kolagenu oraz cechy szkliwienia włókien kolagenowych w warstwie brodawkowatej. Widoczny był także miernie obfity, okołonaczyniowy i śródmiąższowy naciek z limfocy tów w części o hiperchromatycznych jądrach (ryc. 4).

W badaniu immunofenotypowym przeważała ekspresja markera CD3 ze stosunkiem CD4 : CD8 równym $2: 1$. W badaniu PCR nie wykryto monoklonalnego rozrostu limfocytów. Całość badania tkankowego wykluczyła diagnozę chłoniaka zgodnie z wytycznymi rozpoznawania wczesnej fazy mycosis fungoides Polskiego Towarzystwa Dermatologicznego. Rozpoczęto leczenie LS propionianem klobetazolu jeden raz dziennie miejscowo $\mathrm{z}$ poprawą.

Ze względu na pojawienie się $\mathrm{w}$ krótkim czasie kolejnych ognisk choroby włączono metotreksat s.c. $\mathrm{w}$ dawce $15 \mathrm{mg}$ tygodniowo. Po 2 miesiącach terapii w obrębie jednego z ognisk na plecach doszło do rozrostu zmiany guzowatej z wyraźnym naciekiem (ryc. 5), co spowodowało kolejne przyjęcie do oddzia- 


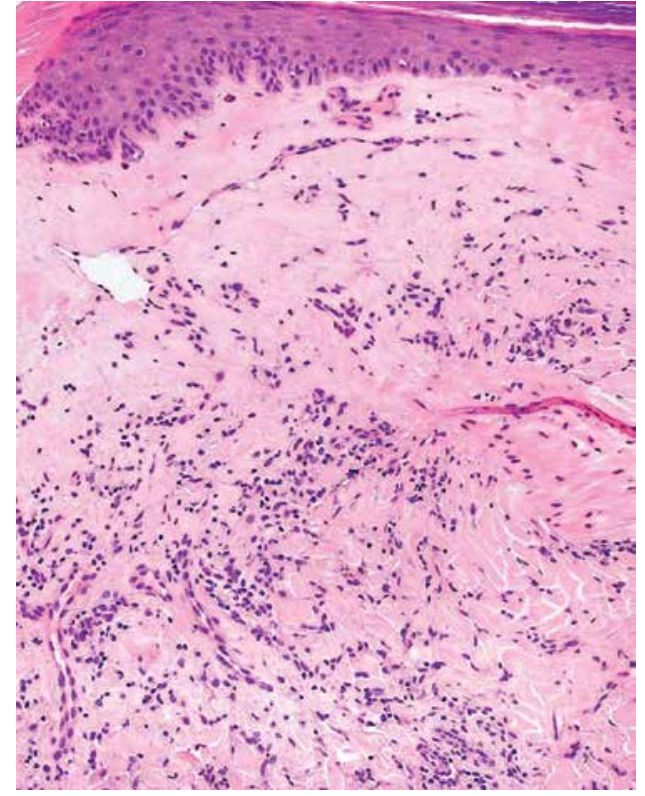

Figure 4. Histopathological image of the patient's skin. Slight perivascular and interstitial infiltration of lymphocytes, in part with hyperchromatic nuclei. Hematoxylin and eosin staining, magnified $100 x$

Rycina 4. Obraz histopatologiczny skóry pacjentki. Miernie obfity, okołonaczyniowy i śródmiąższowy naciek z limfocytów, w części o hiperchromatycznych jądrach. Barwienie hematoksylina + eozyna, powiększenie I00X

infiltration was observed in one of the foci on the back (fig. 5), which resulted in another admission to the Department for further diagnosis. The biopsy specimen collected at that time presented a slightly atrophic epidermis with a slight infiltration of lymphocytes under the epidermis and abundant around hair follicles (mainly CD20+ B lymphocytes: $80 \%$, CD3+ T lymphocytes: 20\%; of which CD4+ lymphocytes constituted 70\%, and CD 8+ lymphocytes 30\% T lymphocytes). Histopathological examination ruled out the diagnosis of mycosis fungoides, and before the next scheduled biopsy the lesion disappeared (clobetasol propionate was applied on this lesion immediately after the first biopsy).

After 1 year of treatment with MTX, new foci of disease appeared suddenly - nodular lesions in the area of the right brow bone and glabella (fig. 6). A decision was made to collect another biopsy specimen, with the determination of the immunophenotype, in which the profuse and diffuse infiltration of small lymphocytes with the following immuno-profile was reported: CD 20+ (80\%), including CD43+60\%, bcl $2+70 \%$, bcl 6- and CD3 + (20 \%), $\kappa-, \lambda$-. Lymphocyte receptor monoclonality was not confirmed in subsequent genetic studies. Morphology of the infiltration was consistent with that of primary cutaneous marginal zone lymphoma (PCMZL) (figs. 7-10). In additional tests, Lyme disease was excluded, and

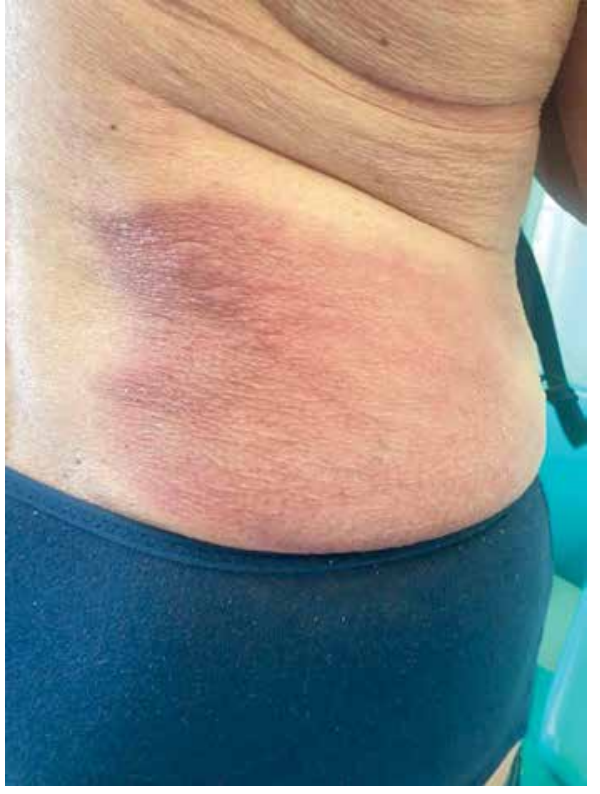

Figure 5. Tumorous lesion within the plaque in the lumbosacral region

Rycina 5. Zmiana guzowata w obrębie ogniska w okolicy lędźwiowo-krzyżowej

łu w celu pogłębienia diagnostyki. Na podstawie pobranego wówczas wycinka opisano nieco atroficzny naskórek z niewielkim naciekiem z limfocytów pod naskórkiem i obfitym wokół mieszków włosowych (głównie limfocyt B CD20+: 80\%, limfocyty T CD3+: $20 \%$; z tego limfocyty CD4+ stanowiły $70 \%$, a limfocyty CD 8+30\% limfocytów T). Badanie histopatologiczne wykluczyło rozpoznanie ziarniniaka grzybiastego, a przed wykonaniem kolejnej planowanej biopsji doszło do remisji zmiany (na którą aplikowano bezpośrednio po wycinku propionian klobetazolu).

Po roku leczenia MTX doszło do nagłego pojawienia się nowych ognisk choroby - zmian guzowatych w okolicy łuku brwiowego prawego oraz gładzizny (ryc. 6). Zdecydowano o pobraniu kolejnego wycinka z oznaczeniem immunofenotypu, w którym opisano obfity i rozlany naciek z drobnych limfocytów o immunoprofilu: CD 20+ (80\%), w tym CD $43+60 \%$, bcl $2+70 \%$, bcl 6- oraz CD3+ $(20 \%), \kappa-, \lambda-$. W następnych badaniach genetycznych nie stwierdzono monoklonalności receptora limfocytów. Morfologia nacieku odpowiadała chłoniakowi B-komórkowemu (primary cutaneous marginal zone lymphoma - PCMZL) (ryc. 7-10). W badaniach dodatkowych wykluczono boreliozę, a elektroforeza białek surowicy krwi wykazała dodatkowy prążek białkowy, w immunofiksacji zidentyfikowany jako białko monoklonalne IgG $\kappa$. Po konsultacji hematologicznej uznano obecność białka $\kappa$ za część obrazu chorobowego i zalecono systematyczne kontrole stężenia białka monoklonalnego i morfologii krwi. Zwiększono dawkę MTX do $20 \mathrm{mg}$ 


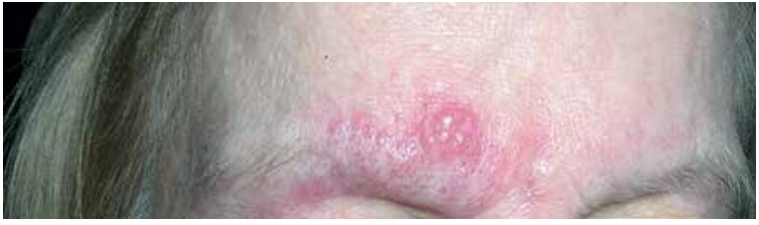

Figure 6. Tumorous lesions located in right superciliary arch and glabella

Rycina 6. Zmiany guzowate w obrębie prawego łuku brwiowego i gladzizny

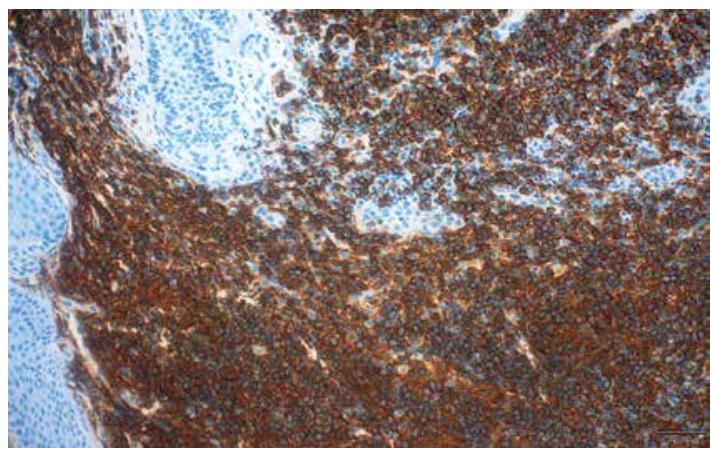

Fgure 8. Expression of CD 20 lymphocytes in lymphoma cells Rycina 8. Ekspresja limfocytów CD 20 w komórkach chłoniakowych

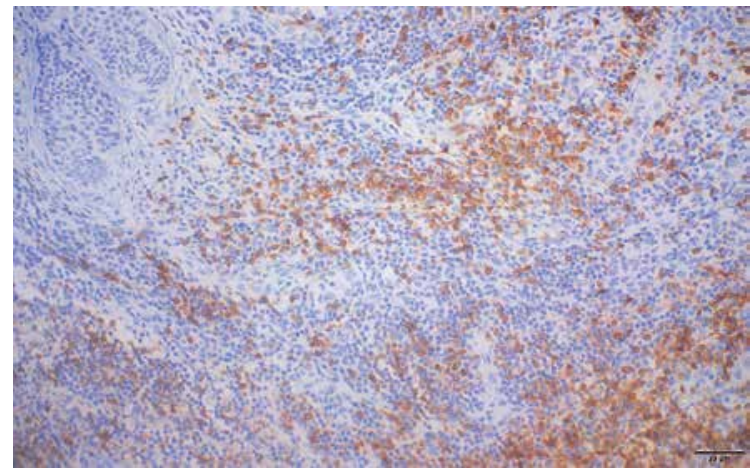

Figure 10. Expression of CD 3 lymphocytes in lymphoma cells Rycina 10. Ekspresja limfocytów CD 3 w komórkach chłoniakowych

electrophoresis of blood serum proteins revealed an additional protein band, identified in immunofixation as the monoclonal $\mathrm{IgG} \kappa$ protein. After hematological consultation, the presence of $\kappa$ protein was considered a part of presentation of the disease, and systematic monitoring of monoclonal protein concentration and blood count was recommended. The MTX dose was increased to $20 \mathrm{mg}$ / week and clobetasol propionate was applied topically, achieving rapid remission of facial tumors. At present, atrophic plaques with

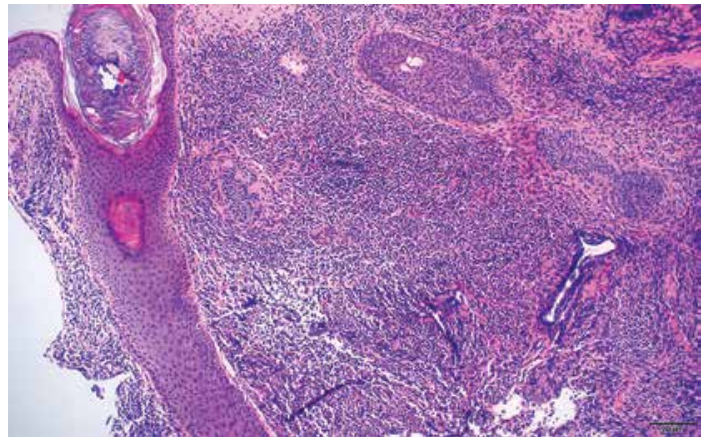

Figure 7. Diffuse small lymphocyte infiltrate - marginal zone lymphoma. Hematoxylin and eosin staining, magnified I00X

Rycina 7. Rozlany naciek z drobnych limfocytów - chłoniak strefy brzeżnej. Barwienie hematoksylina + eozyna, powiększenie I00X

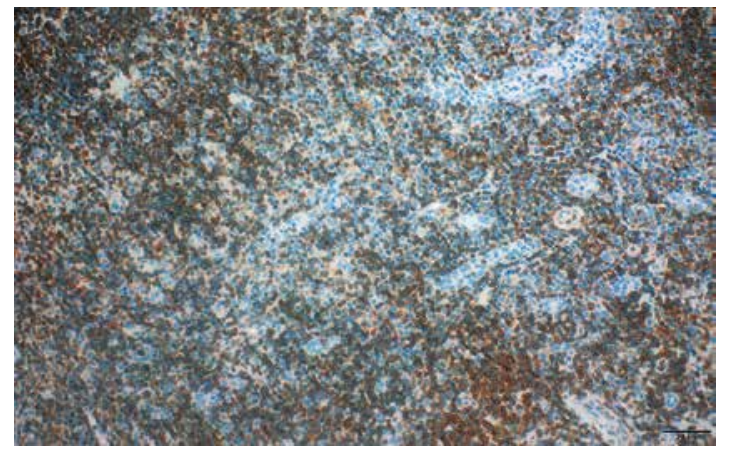

Figure 9. Expression of bcl-2 in lymphoma cells

Rycina 9. Ekspresja bcl-2 w komórkach chłoniakowych

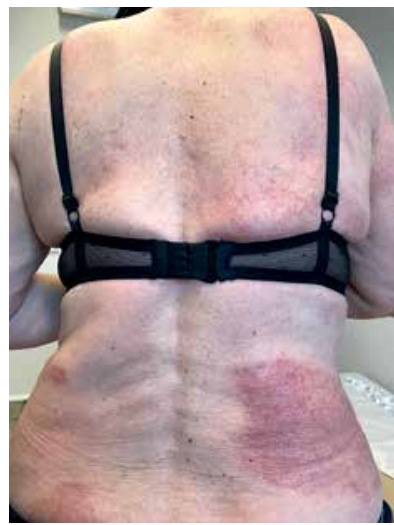

Figure II. The current clinical picture

Rycina II. Aktualny obraz kliniczny

tygodniowo s.c. i zastosowano miejscowo propionian klobetazolu, uzyskując szybką remisję guzów na twarzy. Obecnie utrzymują się atroficzne blaszki z komponentem naczyniowym w miejscu wcześniej nacieczonych zmian w obrębie tułowia. Pacjentka kontynuuje leczenie MTX w dawce $15 \mathrm{mg}$ tygodniowo s.c. (ryc. 11). Wykwity w obrębie sromu uległy remisji i podlegają stałej kontroli ginekologicznej. Pacjentka jest pod stałą opieką dermatologiczną i hematologiczną. 
a vascular component remain in place of previously infiltrated lesions within the trunk. The patient continues MTX treatment at the dose of $15 \mathrm{mg} /$ week s.c. (fig. 11). Vulvar eruptions have remitted and remain under constant gynecological control. The patient is under constant dermatological and hematological control.

\section{DISCUSSION}

Lichen sclerosus (1887, F.H. Hallopeau; “lichen plan atrophique") is a chronic, inflammatory skin disorder most commonly associated with the area of external genitalia in middle-aged and elderly women. Typical eruptions initially take the form of well-defined erythema spots gradually evolving into porcelain-white and atrophic plaques, which may thicken due to chronic irritation caused by pruritus [4]. Early mycosis fungoides (MF) can mimic LS both clinically and histopathologically [5]. Efflorescence in the erythematous stage of MF may be poikylodermic. They typically have the morphology of erythematous spots, but they can also present as hypochromic lesions with slight superficial exfoliation and atrophy (resembling LS plaques) [3]. The presented case aroused oncological concern due to the unusual for LS involvement of a large area of the skin, its rapid course, a distinct vascular component and the investigated infiltration. The patient met all the clinical criteria for the diagnosis of MF according to PTD: presence of progressive macular and erythematous changes, presence of eruptions on the skin not exposed to UV light, variability of the shape and size of eruptions, as well as poikilodermia [6].

Descriptions of opposite clinical situations are available in the literature: mycosis fungoides mimicking LS. Parera et al. described the case of a patient with MF and lymphomatoid papulosis who after many years developed lesions mimicking LS. Researchers described this phenomenon as an additional variant of MF with the morphology of whitish lichen-like plaques, previously described in the literature only once, in 1997 [7]. A similar case was recently presented by Tekin et al. who described it as a variant of interstitial MF [8]. Over the last 30 years, the list of diseases included in the differential diagnosis of MF has significantly increased (atypical forms of MF, the clinical presentation of which differs significantly from the classic one) [9]. Results of a one-way analysis presented by a group of Moroccan authors showed that psoriasis-like MF and MF limited to hands and feet were associated with the longest delay in correct diagnosis (10.5 years on average) [10]. It should be remembered that in the course of MF lesions may be located in the genital area, therefore the initial appearance of lesions in this

\section{OMÓWIENIE}

Liszaj twardzinowy (1887 r., F.H. Hallopeau; lichen plan atrophique) jest przewlekłym, zapalnym schorzeniem skóry, najczęściej występującym w okolicy zewnętrznych narządów płciowych u kobiet w średnim i podeszłym wieku. Charakterystyczne zmiany mają początkowo postać dobrze odgraniczonych plam rumieniowych stopniowo ewoluujących do porcelanowobiałych i zanikowych blaszek, które mogą ulegać pogrubieniu wskutek przewlekłego drażnienia wywołanego świądem [4]. Wczesna postać ziarniniaka grzybiastego (mycosis fungoides - MF) może imitować LS zarówno klinicznie, jak i histopatologicznie [5]. Wykwity w stadium rumieniowym MF mogą być poikilodermiczne. Typowo mają morfologię rumieniowych plam, ale objawiać się mogą także jako hipochromiczne zmiany z nieznacznym złuszczaniem powierzchni i atrofią (przypominają blaszki LS) [3]. Przedstawiony przez nas przypadek budził niepokój onkologiczny ze względu na nietypowe dla LS zajęcie dużej powierzchni skóry, szybki przebieg, wyraźny komponent naczyniowy oraz wyczuwalny naciek. Chora spełniała wszystkie kliniczne kryteria rozpoznawania MF według PTD: obecność postępujących zmian plamisto-rumieniowych, występowanie wykwitów na skórze nieeksponowanej na światło UV, zmienność kształtów i rozmiarów wykwitów, a także poikilodermia [6].

W piśmiennictwie dostępne są opisy odwrotnej sytuacji klinicznej: ziarniniaka grzybiastego imitującego LS. Parera i wp. opisali przypadek pacjenta z MF i lymphomatoid papulosis, który po wielu latach rozwinął zmiany imitujące LS. Badacze opisali to zjawisko jako dodatkowy wariant MF o morfologii białawych liszajowatych blaszek, wcześniej opisywany w literaturze zaledwie jednokrotnie w $1997 \mathrm{r}$. [7]. Podobny przypadek przedstawili ostatnio Tekin i wsp., określając go jako wariant interstitial MF [8]. Przez ostatnie 30 lat lista schorzeń uwzględnianych w diagnostyce różnicowej MF znacząco się wydłużyła (atypowe postacie MF, których obraz kliniczny znacznie odbiega od klasycznego obrazu choroby) [9]. Wyniki jednoczynnikowej analizy grupy marokańskich autorów wykazały, że postaci łuszczycopodobna oraz ograniczona do rąk i stóp ziarniniaka grzybiastego wiążą się z największym opóźnieniem w postawieniu prawidłowej diagnozy (średnio 10,5 roku) [10]. Należy pamiętać, że zmiany w przebiegu MF mogą lokalizować się w okolicy genitalnej, dlatego pierwotne pojawienie się zmian $\mathrm{w}$ tej okolicy nie wyklucza tej diagnozy [11]. Różnorodność obrazów choroby w wariancie poikilodermicznym wymusza diagnostykę w kierunku MF także w nietypowych przypadkach postępujących plamic barwnikowych (pigmented purpuric dermatoses - PPD). Do 
area does not exclude this diagnosis [11]. Diversity of the presentation of the disease in the poikylodermic variant necessitates the diagnosis of MF also in atypical cases of progressive pigmented purpuric dermatoses (PPD). Clinical factors that lead to the diagnosis of MF in patients with PPD symptoms include: progressive nature of lesions, a large percentage of the skin area covered by purpura, and duration of the disease exceeding 1 year [12]. The relationship between $\mathrm{MF}$ and PPD is a rare but recognized phenomenon. A particularly spectacular clinical presentation of MF in the pigmented purpura-like MF variant resembling tiger stripes has been described recently [13].

A key step in the diagnosis of cutaneous lymphomas is a tissue test with the determination of the immunophenotype and receptor clonality. Superficial lymphocytic infiltration, epidermotropism without spongiosis, and lymphocyte atypia (cells with enlarged, hyperchromatic nuclei or nuclei with an irregular, cerebral outline) are characteristic for mycosis fungoides [6]. Early-stage MF is characterized by a superficial streaky lymphocytic infiltrate. In the study by Kelati et al., the most common histological features of MF included epidermotropism (89.4\%), superficial lymphocytic infiltration $(70.1 \%)$, bright halo cytoplasm - Lutzner cells (47.4\%) and the presence of Pautrier microabscesses (29.8\%) [10]. Characteristic histopathological features of LS include: atrophic epidermis, focal thickening of the basal membrane, streaked lymphocyte infiltration with vacuolization of the dermal-epidermal junction, and homogenization of collagen in the papillary layer of the dermis [14].

An auxiliary diagnostic criterion in the diagnosis of cutaneous lymphomas is the presence of a clonal rearrangement of TCR receptors or immunoglobulin chains. However, clonal proliferation may not be detected at the early stage of MF. Interestingly, it was described in LS [6]. According to majority of sources, monoclonality concerns only $50-60 \%$ of MF cases, therefore its presence or absence is not an absolute diagnostic criterion $[8,14]$. A new molecular technique is gradually being implemented - high-throughput sequencing of the TCR receptor, which enables greater sensitivity and specificity in the diagnosis of MF than the standardized TCR $\gamma$ analysis by means of the PCR technique [9].

In the immunohistochemical study, the markers used in the pre-screening of lymphomas include: CD20 (positive in B-cell lymphomas), CD3 (present in T-cell proliferation) and CD45 (a marker of myeloid leukocytes) [13]. The immunophenotype typical for MF reflects the pattern of Th2 cell cytokine production: CD3 +, CD4 +, CD45RO + and CD8 [15]. Qualitative expression of $\mathrm{CD}$ markers is expressed by the CD4 : CD8 ratio, which is $2: 1$. It is typically increased czynników klinicznych, które naprowadzają na rozpoznanie MF u chorych z objawami PPD, należą: postępujący charakter zmian, duży procent powierzchni skóry zajętej przez zmiany plamicze oraz czas trwania choroby przekraczający rok [12]. Związek między MF a PPD jest rzadkim, jednak uznanym zjawiskiem. Ostatnio opisano szczególnie spektakularny obraz kliniczny MF w wariancie plamiczym (pigmented purpura-like MF) przypominający pasy tygrysa [13].

Kluczowym krokiem w diagnostyce chłoniaków skóry jest badanie tkankowe z oznaczeniem immunofenotypu oraz klonalności receptora. Dla ziarniniaka grzybiastego charakterystyczny jest powierzchowny naciek limfocytarny, epidermotropizm bez cech spongiozy, atypia limfocytów (komórki z powiększonymi, hiperchromatycznymi jądrami lub jądrami o nieregularnym, mózgokształtnym obrysie) [6]. Ziarniniak grzybiasty we wczesnych stadiach charakteryzuje się powierzchownym pasmowatym naciekiem limfocytarnym. W badaniu Kelati i wsp. do najczęściej występujących cech histologicznych MF należały: epidermotropizm $(89,4 \%)$, powierzchowny naciek limfocytarny $(70,1 \%)$, jasna cytoplazma „halo" - komórki Lutznera $(47,4 \%)$ oraz występowanie mikroropnii Pautriera $(29,8 \%)$ [10]. Do charakterystycznych cech histopatologicznych LS można zaliczyć: atroficzny naskórek, ogniskowe zgrubienie błony podstawnej, pasmowaty naciek $\mathrm{z}$ limfocytów $\mathrm{z}$ wakuolizacją złącza skórno-naskórkowego oraz homogenizację kolagenu w warstwie brodawkowatej skóry właściwej [14].

Pomocniczym kryterium diagnostycznym w rozpoznaniu chłoniaków skóry jest obecność klonalnej rearanżacji receptorów TCR lub łańcuchów immunoglobulin, jednak klonalna proliferacja może nie zostać wykryta na wczesnym etapie MF, a, co ciekawe, była opisywana w LS [6]. Monoklonalność według większości źródeł dotyczy tylko 50-60\% przypadków MF, dlatego jej obecność lub brak nie stanowi bezwzględnego kryterium rozpoznania $w$ diagnostyce $[8,14]$. Stopniowo wdrażana jest nowa technika molekularna - wysokowydajne sekwencjonowanie receptora TCR, która umożliwia większą czułość i swoistość w diagnostyce MF niż standardowo wykorzystywana analiza TCR y za pomocą techniki PCR [9].

$\mathrm{W}$ badaniu immunohistochemicznym do markerów używanych we wstępnej kwalifikacji chłoniaków należą: CD20 (pozytywny w chłoniakach B-komórkowych), CD3 (obecny w rozrostach T-komórkowych) i CD45 (marker leukocytów pochodzenia szpikowego) [13]. Typowy dla MF immunofenotyp jest odzwierciedleniem wzorca produkcji cytokin komórek Th2: CD3+, CD4+, CD45RO+ i CD8 [15]. Jakościową ekspresję markerów CD wyraża stosunek CD4 : CD8, który wynosi 2: 1. Zwiększony jest typowo w klasycznej postaci naciekowej ziarniniaka grzybiastego lub chłoniakach T-komórkowych, zmniej- 
in classic infiltrative mycosis/T-cell lymphomas, but decreases in advanced stages of the disease. It should be remembered that there are atypical variants of Tcell lymphomas with a reduced CD4 : CD8 ratio. In Sezary's syndrome, the ratio is usually greater than 10 [16].

It should be particularly emphasized that correctly performed skin biopsies (punch or surgical - deep biopsies) from various morphologically different lesions must be reproduced, not only in order to establish the diagnosis, but also in the search for possible changes in the cytology of lymphoma cells (e.g., large cell transformation), which is emphasized by expert guidelines [6].

LS is classified as a cutaneous pseudo-lymphoma - a heterogeneous group of conditions defined as benign, reactive hyperplasia of $\mathrm{T}$ or $\mathrm{B}$ lymphocytes, that can clinically and histologically mimic lymphomas, but have a tendency to resolve spontaneously. In most cases, etiology of the disease is unknown [17]. Cutaneous pseudo-lymphomas can be divided according to the cells that dominate in the lymphocytic infiltration (table 1) [18].

Cutaneous pseudo-lymphomas are diseases that respond well to glucocorticosteroidsm (GCS). One of the latest reports by Chinese researchers put forward the thesis that an excellent response to properly administered GCS therapy may be used to differentiate lymphoma from pseudo-lymphoma [17].

Primary cutaneous T-cell lymphomas (PCTCL) are characterized by a slow course resulting from the coincidence of inflammatory and neoplastic phenomena, which is confirmed by cases of lymphoma development in the course of severe atopic dermatistis (AD). Already in the early stages of the disease, proliferation of lymphocytes is under the special supervision sza się natomiast w zaawansowanych stadiach choroby. Należy pamiętać, że występują nietypowe warianty chłoniaków T-komórkowych z obniżonym stosunkiem CD4 : CD8. W zespole Sezary'ego stosunek ten jest zazwyczaj większy niż 10 [16].

Warto podkreślić fakt, że konieczna jest powtarzalność prawidłowo wykonywanych biopsji skóry (sztancowych lub chirurgicznych - głębokich) z różnych morfologicznie zmian w celu nie tylko ustalenia rozpoznania, lecz także poszukiwania ewentualnych zmian w cytologii komórek chłoniaka (np. transformacja wielkokomórkowa), co podkreślają wytyczne eksperckie [6].

Liszaj twardzinowy zaliczany jest do rzekomych chłoniaków skóry - heterogennej grupy schorzeń definiowanych jako łagodne, odczynowe rozrosty limfocytów T lub B, które klinicznie i histologicznie mogą naśladować chłoniaki, ale mają tendencję do samoistnego ustępowania. W większości przypadków etiologia schorzenia jest nieznana [17]. Pseudochłoniaki skórne można podzielić w zależności od dominujących w nacieku limfocytarnym komórek (tab. 1) [18].

Pseudochłoniaki skórne należą do jednostek chorobowych szczególnie dobrze odpowiadających na glikokortykosteroidy (GKS). W jednym z ostatnich doniesień chińskich badaczy wysunięto tezę, że doskonała odpowiedź na właściwie stosowaną terapię GKS może służyć do różnicowania chłoniaka od pseudochłoniaka [17].

Chłoniaki T pierwotnie skórne (primary cutaneous T-cell lymphoma - PCTCL) charakteryzują się powolnym przebiegiem wynikającym z koincydencji zjawisk zapalnych i nowotworowych, co potwierdzają przypadki rozwoju chłoniaków w przebiegu ciężkiego atopowego zapalenia skóry (AZS). Już we wczesnych etapach choroby rozrost chłoniakowych limfocytów jest pod szczególnym nadzorem układu immunologicznego (wykazano występowanie dużej liczby poliklonalnych komórek CD 8).

Table I. Characteristics of particular pseudolymphomas types according to the predominant cells in the infiltrate

Tabela I. Charakterystyka poszczególnych typów pseudochłoniaków według dominującego typu komórek w nacieku

\begin{tabular}{|c|c|}
\hline $\begin{array}{l}\text { Pseudolymphomas - predominant lymphocyte subtype/ } \\
\text { Pseudochłoniaki - dominujący typ limfocytów }\end{array}$ & Disease entity/Jednostka chorobowa \\
\hline T-cell/T-komórkowe & $\begin{array}{l}\text { Lymphocytic infiltration Jessner-Kanof/Naciek limfocytarny Jessnera-Kanofa } \\
\text { Actinic reticuloid/Actinic reticuloid } \\
\text { Lymphomatoid contact dermatitis/Odczyn limfocytarny w przebiegu } \\
\text { wyprysku kontaktowego } \\
\text { Lichenoid inflammatory diseases e.g. LS/Liszajopodobne choroby zapalne, } \\
\text { np. LS }\end{array}$ \\
\hline B-cell/B-komórkowe & $\begin{array}{l}\text { Lymphocytoma/Lymphocytoma } \\
\text { Arthropod-bite reaction, tattoo link-related, vaccination/Prowokowane } \\
\text { ukąszeniami przez stawonogi, tatuażem, szczepieniami }\end{array}$ \\
\hline Mixed ( $\mathrm{T}$ and B- cells)/Mieszane (T i B- komórkowe) & Drug induced/Indukowane lekami \\
\hline CD30-positive/CD30-dodatnie & $\begin{array}{l}\text { Scabies/Świerzb } \\
\text { HSV infection/Infekcja HSV } \\
\text { Milker's nodules/Guzki dojarek }\end{array}$ \\
\hline Non-classifiable/Niesklasyfikowane & $\begin{array}{l}\text { Descriptive diagnosis for other atypical lymphocytic infiltration/Opisowa } \\
\text { diagnoza dla innych atypowych rozrostów limfocytarnych }\end{array}$ \\
\hline
\end{tabular}


of the immune system (a presence of a large number of polyclonal CD 8 cells was demonstrated). Hence, it was theorized that impaired cellular immunity during the disease progression was responsible for the uncontrolled proliferation of the malignant cell clone, and thus rapid progression of the disease [19].

Primary cutaneous B-cell lymphomas (PCBCL) account for $20-25 \%$ of all cutaneous lymphomas and are divided into 3 major subtypes: extra-nodal marginal zone lymphomas (PCMZL), primary cutaneous follicle-center lymphomas (PCFCL), limb type cutaneous diffuse large B-cell lymphomas (PCDLBCL-LT).

PCMZL is a rare type. It mainly affects the middle-age population and manifests itself as single or multiple lesions of erythematous or brown-colored nodules or plaques on the trunk and limbs with no generalized symptoms. It belongs to indolent neoplasms, rarely becomes disseminated, but it is characterized by recurrence $[20,21]$. Treatment depends on the degree of skin involvement and includes radiotherapy or surgical excision, antibiotic therapy in the case of positive Borrelia burgdorferi antibodies (negative results in the reported patient) and chemoand immunotherapy in the case of generalized skin lesions (mainly with rituximab) [22].

The presence of the $\kappa$ light chain observed in our patient's blood has been determined by the hematologist as an element of presentation of the disease. However, in the event of recurrence of symptoms, extensive diagnostics is planned to determine the type of monoclonal gammapathy, including light-chain monoclonal gammapathy of undefined significance (LC-MGUS). According to the currently accepted classification, a plasmacytoma originating primarily from the skin is a variant of PCMZL (PCMZL, plasmatic variant) - an extremely rare (even unique) variant, which is characterized by the presence of a very large number of plasmocytes within lymphoma cells $[23,24]$.

The occurrence of LS in the context of the accompanying gammapathy in the reported patient suggests a pseudo-scleroderma syndrome, considering high clinical and histopathological similarity of lichen scleroderma and scleroderma. Plasmocyte dyscrasia can manifest itself as a cutaneous paraneopastic syndrome, e.g., pseudo-sclerodermic. In the work of Magro et al. the onset of scleroderma/eosinophilic fasciitis was in most cases related to the initial diagnosis and/or exacerbation of the underlying disease [25].

Possible therapeutic options for LS include local and systemic treatments. Very strong glucocorticosteroids (clobetasol) are recommended as the therapy of choice, highly effective particularly in vulvar LS. Used properly (on mucous membranes), they are safe in long-term therapy and do not cause atrophy or an increased risk of infection [26]. Alternatively, local tri-
Dlatego wysnuto teorię, że upośledzenie odporności komórkowej w trakcie postępu choroby odpowiada za niekontrolowaną proliferację złośliwego klonu komórek, a także szybką progresję choroby [19].

Pierwotne chłoniaki skóry B-komórkowe (primary cutaneous B-cell lymphoma - PCBCL) stanowią 20-25\% wszystkich chłoniaków skóry i dzielą się na 3 główne podtypy: pozawęzłowe chłoniaki strefy brzeżnej (PCMZL), pierwotne skórne chłoniaki z ośrodków rozmnażania (PCFCL) oraz pierwotne skórne chłoniaki rozlane z dużych komórek B typu kończynowego (PCDLBCL-LT).

PCMZL jest rzadkim typem, dotyczy głównie populacji wieku średniego i objawia się jako pojedyncze lub mnogie ogniska rumieniowo lub brunatno zabarwionych guzków lub blaszek na tułowiu i kończynach bez towarzyszących objawów ogólnych. Należy do nowotworów indolentnych, rzadko przechodzi w formę rozsianą, jednak cechuje się nawrotowością $[20,21]$. Leczenie zależy od stopnia zajęcia skóry i obejmuje radioterapię lub chirurgiczne wycięcie, antybiotykoterapię w przypadku stwierdzenia dodatnich przeciwciał Borrelia burgdorferi (u przedstawionej pacjentki wyniki ujemne) oraz chemio- i immunoterapię w przypadku uogólnionych zmian skórnych (głównie rytuksymab) [22].

Obserwowana we krwi u naszej pacjentki obecność łańcucha lekkiego $\kappa$ została określona przez hematologa jako element obrazu chorobowego, niemniej w razie ponawiania się objawów planowana jest szeroka diagnostyka w celu określenia typu gammapatii monoklonalnej, w tym gammapatii monoklonalnej o nieokreślonym znaczeniu łańcuchów lekkich (light-chain monoclonal gammopathy of undetermined significance - LC-MGUS). Według obecnie przyjętej klasyfikacji plazmocytoma wywodzący się pierwotnie ze skóry to odmiana PCMZL (PCMZL, plasmatic variant) - niezmiernie rzadki (wręcz unikalny) wariant, który cechuje się obecnością bardzo dużej liczby plazmocytów w obrębie komórek chłoniaka [23, 24].

Wystąpienie LS w przypadku towarzyszącej gammapatii u prezentowanej przez nas pacjentki nasuwa przypuszczenie zespołu rzekomotwardzinowego z uwagi na wysokie podobieństwo kliniczne i histopatologiczne LS i twardziny. Dyskrazja plazmocytów może manifestować się jako skórny zespół paraneopastyczny, m.in. pseudotwardzinowy. W pracy Magro i wsp. początek wystąpienia stwardnień w przebiegu twardziny lub eozynofilowego zapalenia powięzi był w większości przypadków związany czasowo z początkową diagnozą i/lub zaostrzeniem choroby podstawowej [25].

Możliwe opcje terapeutyczne leczenia LS obejmują leczenie miejscowe i ogólne. Jako terapię z wyboru, zwłaszcza wysoce skuteczną w LS sromu, rekomenduje się bardzo silne GKS (klobetazol). Stosowane właściwie (na błony śluzowe) są bezpieczne w długoterminowej terapii i nie powodują atrofii lub zwiększonego ryzyka 
amcinolone injections are proposed for a small area of affected skin. The use of topical calcineurin inhibitors remains controversial - it is believed that when applied to the genital area, they may increase the risk of developing squamous cell carcinoma and reactivation of HPV infection. UVA1 and PUVA phototherapy is an effective option for patients with extensive eruptions that do not respond to topical GCS. Among systemic therapies, retinoids (acitretin, isotretinoin) at doses of 10-50 mg/day can be used. However, evaluation of the effectiveness of this therapy is possible only after several months of duration. Immunosuppressive therapy is typically not indicated in the treatment of lichen sclerosus. However, in some patients with particularly resistant course of the disease, a combination of pulses of high doses of intravenous GCSs and low doses of MTX leads to clinical improvement [27].

\section{CONCLUSIONS}

Cutaneous lymphomas pose a particular challenge in everyday dermatological practice as they can mimic both common and rare skin diseases. Patients with these dermatoses should be under constant, preferably multidisciplinary (dermatologist-hematologistradiotherapist-pathomorphologist-psychologist/ psychiatrist) care in reference centers. An atypical manifestation or course of a skin disease should each time lead to increased oncological vigilance and absolute recommendation of skin biopsy [8].

\section{CONFLICT OF INTEREST}

The authors declare no conflict of interest. infekcji [26]. Alternatywnie proponowane są miejscowe iniekcje $\mathrm{z}$ triamcynolonu $\mathrm{w}$ przypadku niewielkiej powierzchni zajętej skóry. Stosowanie miejscowych inhibitorów kalcyneuryny jest kontrowersyjne - przypuszcza się, że stosowane w okolicy narządów płciowych mogą zwiększać ryzyko rozwoju raka kolczystokomórkowego i reaktywacji zakażenia HPV. Skuteczną opcją dla pacjentów z rozległymi wykwitami nieodpowiadającymi na miejscowe GKS jest fototerapia UVA1 oraz PUVA. Spośród terapii ogólnych można zastosować retinoidy (acytretyna, izotretynoina) w dawkach 10-50 $\mathrm{mg}$ /dobę, jednak ocena skuteczności tej terapii jest możliwa dopiero po kilku miesiącach trwania. Leczenie immunosupresyjne nie jest typowo wskazane $\mathrm{w}$ terapii LS, jednak u niektórych pacjentów ze szczególnie opornym przebiegiem choroby kombinacja pulsów wysokich dawek dożylnych GKS oraz niskich dawek MTX prowadzi do poprawy stanu klinicznego [27].

\section{WNIOSKI}

Chłoniaki skóry stanowią szczególne wyzwanie w codziennej praktyce dermatologicznej, gdyż mogą imitować zarówno powszechne, jak i rzadkie choroby skóry. Pacjenci z tymi dermatozami powinni znajdować się w stałej, najlepiej wielospecjalistycznej (zespół dermatolog-hematolog-radioterapeutapatomorfolog-psycholog/psychiatra) opiece w ośrodkach referencyjnych. Nietypowa manifestacja lub przebieg schorzenia skóry powinien każdorazowo skłaniać do wzmożenia czujności onkologicznej i bezwzględnie zalecanego ponawiania biopsji skóry [8].

\section{KONFLIKT INTERESÓW}

Autorzy nie zgłaszają konfliktu interesów.

\section{References}

Piśmiennictwo

1. Powell J.J., Wojnarowska F.: Lichen sclerosus. Lancet 1999, 353, 1777-1783.

2. Romero-Pérez D., Blanes Martínez M., Encabo-Durán B.: Cutaneous pseudolymphomas. Actas Dermosifiliogr 2016, 107, 640-651.

3. Yamashita T., Fernandes Abbade L.P., Alencar Marques M.E., Alencar Marques S.: Mycosis fungoides and Sézary syndrome: clinical, histopathological and immunohistochemical review and update. An Bras Dermatol 2012, 87, 817-830.

4. Chamli A., Souissi A.: Lichen Sclerosus. In: StatPearls [Internet]. Treasure Island (FL): StatPearls Publishing; 2021.

5. Reddy K., Bhawan J.: Histologic mimickers of mycosis fungoides: a review. J Cutan Pathol 2007, 34, 519-525.

6. Sokołowska-Wojdyło M., Maj J., Robak E., Placek W., Wojas-Pelc A., Jankowska-Konsur A., et al.: Primary cutaneous lymphomas - diagnostic and therapeutic guidelines of the Polish Dermatological Society. Dermatol Rev 2017, 104, $243-268$.

7. Parera E., Toll A., Gallardo F., Bellosillo B., Pujol R.M., Marti R.: Lichen sclerosus et atrophicus-like lesions in mycosis fungoides. Br J Dermatol 2007, 157, 411-413.

8. Tekin B., Kempf W., Seckin D., Ergun T., Yucelten D., Demirkesen C.: Interstitial mycosis fungoides with lichen sclerosuslike clinical and histopathological features. Am J Dermatopathol 2016, 38, 138-143.

9. Hodak E., Amitay-Laish I.: Mycosis fungoides: a great imitator. Clin Dermatol 2019, 37, $255-267$. 
10. Kelati A., Gallouj S., Tahiri L., Harmouche T., Mernissi F.Z.: Defining the mimics and clinico-histological diagnosis criteria for mycosis fungoides to minimize misdiagnosis. Int J Women's Dermatol 2017, 3, 100-106.

11. Citarella L., Massone C., Kerl H., Cerroni L.: Lichen sclerosus with histopathologic features simulating early mycosis fungoides. Am J Dermatopathol 2003, 25, 463-465.

12. Jaworek A.K., Englert K., Spałkowska M., Dyduch G., Zalewski A., Wojas-Pelc A.: Atypical presentation of schamberg's disease - diagnostic challenges. Dermatol Rev 2019, 106, 34-45.

13. Ahman A., Semkova K., Stefanato C.M., Calonje E.J., Choczaj-Kukula A., Palamaras I.: Tiger-like mycosis fungoides: an unusual clinical presentation of a rare variant of mycosis fungoides. Dermatol Online J 2019, 25, 13030/qt0w1035f7.

14. Suchak R., Verdolini R., Robson A., Stefanato C.M.: Extragenital lichen sclerosus et atrophicus mimicking cutaneous T-cell lymphoma: report of a case. J Cutan Pathol 2010, 37, 982-986.

15. Ito A., Sugita K., Ikeda A., Yamamoto O.: CD4/CD8 Double-negative mycosis fungoides: a case report and literature review. Yonago Acta Medica 2019, 62, 153-158.

16. Campbell S.M., Peters S.B., Zirwas M.J., Wong H.K.: Immunophenotypic diagnosis of primary cutaneous lymphomas. J Clin Aesthet Dermatol 2010, 3, 21-25.

17. Tian Z., Shiyu Z., TaoW., Li L., Yuehua L., Honghong J.: Lymphoma or pseudolymphoma: a report of six cases and review of the literature. Dermatol Ther 2019, 32, e12807.

18. Miguel D., Peckruhn M., Elsner P.: Treatment of cutaneous pseudolymphoma: a systematic review. Acta Derm Venereol 2018, 98, 310-317.

19. Sokołowska-Wojdyło M., Roszkiewicz J., Zaucha J.M., Barańska-Rybak W., Kugowska-Umerl H.: Diagnostic and therapeutic problems in a case of mycosis fungoides diagnosed first as actinic reticuloid. Dermatol Rev 2010, 97, 196-202.

20. Malachowski S.J., Sun J., Pei-Ling C., Seminario-Vidal L.: Diagnosis and management of cutaneous B-cell lymphpomas. Dermatol Clin 2019, 37, 443-454.

21. Vitiello P., Sica A., Ronchi A., Caccavale S., Franco R., Argenziano G.: Primary cutaneous B-cell lymphomas: an update. Front Oncol 2020, 10, 651

22. Wilcox R.A.: Cutaneous B-cell lymphomas: 2019 update on diagnosis, risk stratification, and management. Am J Hematol $2018,93,1427-1430$.

23. Lima M.: Cutaneous primary B-cell lymphomas: from diagnosis to treatment. An Bras Dermatol 2015, $90,687-706$.

24. Willemze R., Jaffe E.S., Burg G., Cerroni L., Berti E., Swerdlow S.H., et al.: WHO-EORTC classification for cutaneous lymphomas. Blood 2005, 105, 3768-3785.

25. Magro C.M., Iwenofu H., Nuovo G.J.: Paraneoplastic scleroderma-like tissue reactions in the setting of an underlying plasma cell dyscrasia: a report of 10 cases. Am J Dermatopathol 2013, 35, 561-568.

26. Kai A., Lewis F.: Long-term use of an ultrapotent topical steroid for the treatment of vulval lichen sclerosus is safe. J Obstet Gynaecol 2016, 36, 276-277.

27. Bolognia J., Jorizzo J.L., Schaffer J.V.: Dermatology. Elsevier Saunders, Philadelphia 2018.

Received: 1.04 .2021

Accepted: 2.06.2021

Otrzymano: $1.04 .2021 \mathrm{r}$.

Zaakceptowano: $2.06 .2021 \mathrm{r}$

How to cite this article

Oszywa A., Jaworek A.K., Dyduch G., Giza A., Wojas-Pelc A.: Lichen sclerosus mimicking mycosis fungoides preceding B-cell lymphoma - diagnostic challenges. Dermatol Rev/Przegl Rev 2021, 108, 202-212. DOI: https://doi.org/10.5114/dr.2021.108611. 